Vol. 14, $n^{\circ} 1$ | 2010

Varia

\title{
Policing the Ghetto: Jewish East London, 1880-1920
}

\section{David Englander}

\section{(2) OpenEdition \\ Journals}

Electronic version

URL: https://journals.openedition.org/chs/1141

DOI: $10.4000 /$ chs. 1141

ISSN: 1663-4837

\section{Publisher}

Librairie Droz

\section{Printed version}

Date of publication: 1 May 2010

Number of pages: $29-50$

ISBN: 978-2-600-01425-0

ISSN: 1422-0857

\section{Electronic reference}

David Englander, "Policing the Ghetto: Jewish East London, 1880-1920", Crime, Histoire \& Sociétés / Crime, History \& Societies [Online], Vol. 14, $n^{\circ} 1 \mid$ | 2010, Online since 01 May 2013, connection on 22 March 2022. URL: http://journals.openedition.org/chs/1141 ; DOI: https://doi.org/10.4000/chs.1141 


\title{
Policing the Ghetto Jewish East London, 1880-1920
}

\author{
David Englander
}

\begin{abstract}
In the generation before the First World War Whitechapel, in East London, became home to one of the largest immigrant communities in England. There were few points of contact between this community and those charged with policing it. The immigrants came from a world suspicious of men in uniform. The police, for their part, perceived the Jewish community as peaceable, sober and relatively free from criminality; but the police also shared the indigenous community's suspicion of aliens. Concern about political extremism brought closer police involvement and the First World War brought increased supervision. However the presence of respectable middleclass Anglo-Jewry with a strong sense of community solidarity as well as a strong sense of English values appears to have contributed to a significant contrast between Jewish-police relations and Irish-police relations across the period.
\end{abstract}

Au cours de la génération précédant la Première Guerre mondiale, le quartier de Whitechapel, dans l'est de Londres, vit s'établir l'une des plus importantes communautés immigrées d'Angleterre. Les relations entre cette communauté et ceux qui étaient chargés d'y faire la police étaient réduites. Les immigrants provenaient d'un monde méfiant envers l'uniforme. Pour sa part, la police percevait la communauté juive comme pacifique, sobre et relativement dépourvue de délinquance, tout en partageant la méfiance des autochtones envers les étrangers. La préoccupation vis-à-vis de l'extrémisme politique poussa la police à s'intéresser davantage à eux et la guerre suscita une surveillance accrue. Néanmoins, l'existence d'une classe moyenne anglo-juive respectable, pourvue à la fois d'un sentiment communautaire affirmé et d'un fort attachement aux valeurs anglaises, semble avoir fortement différencié les relations entre les Juifs et la police de celles que cette dernière entretenait avec les Irlandais, durant la même période.

\section{INTRODUCTION}

I ondon before the First World War possessed a substantial minority population. The riverside districts were noted for their exotic mixture of seafarers,

1 David Englander was Reader in History at the Open University when he died in 1999. Colleagues knew that he was working on this paper up until the moment that he died, but feared that it had been lost. When the department moved offices early in 2009, a draft of the paper was found in a cupboard. It has been revised and slightly updated by Clive Emsley. 
travellers and settlers. There were French and Italian communities in Clerkenwell and Saffron Hill; the Dutch lived in Spitalfields. More numerous still were the Germans who, until the onset of Jewish immigration from Easter Europe, constituted the largest single immigrant group in London ${ }^{2}$. The status of the Irish was different, but the many 'colonies' in which they lived seemed scarcely less alien to middle class contemporaries ${ }^{3}$. The problems posed by the policing of such communities, however, has attracted little scholarly attention. Traditional police history tends to be narrative in form, celebratory in tone and largely preoccupied with questions of organization and institutions ${ }^{4}$. It has been challenged, though by no means displaced, by a revisionist historiography that is critical and more sociologically informed. Attention has, in consequence, shifted towards the study of police-public relations and the ways in which consent in working-class communities was constructed and reconstructed in an on-going process of negotiation. The influence of bureaucracy and the growth of police professionalism upon the maintenance of public order have also received a good deal of attention. Awareness has been raised and scholars made more familiar with the process and diversity of policing in urban Britain $^{5}$. Some curious lacunae in the literature nevertheless remain. Little work has been done on the policing of minorities. The Irish have fared best. But it remains difficult to assess the importance of scholarship in this area simply because we have so few studies of other minority populations as a basis for comparison ${ }^{6}$. Of the policing of the mixed populations of Limehouse and Shadwell, for example, or of the foreign communities of West Central London, we know nothing. The policing of Jewish East London likewise awaits its historian. Jewish criminality has been identified as a suitable subject for historical inquiry; a recent study focused on 'The Jewish Association for the Protection of Girls and Women' has shown how it responded to 'Jewish criminality', particularly to white slavery. Yet the policing of the immigrant area of settlement has scarcely begun to be considered ${ }^{7}$.

The following article constitutes a preliminary exploration of the policing of the Whitechapel-Spitalfields district during its formative stages as the largest of immigrant quarters. Its aims are fourfold. The first section is concerned with summarising the growth of the settlement locality and identifies the sources of inter-communal conflict. Police-community relations are then explored through the eyes of serving officers in the Jewish quarter. The ways in which the occupational culture of the police and the dominant ideologies of front line officers affected encounters with the minority are noted and the influence of Jewish communal leadership upon the management of the minority is discussed. The final section examines the disruptive effects of mass industrialised warfare upon minority-majority relationships. It is suggested that, while much remains to be done, our cursory examination of Jewish

2 On the Germans, see Panayi (1991); on the Italians, see Sponza (1988); on the diverse foreign populations, see TNA: HO 45/11522/87235. Census of Aliens Taken in the United Kingdom in 1918.

3 On the situation of the Irish, see Lees (1979); O'Tauthaigh (1981); Swift, Gilley (1985).

4 See, for example, Critchley (1967); Ascoli (1979).

5 The new historiography and its achievements are well represented in Emsley (1996, 2010).

6 See Davis (1989).

7 Knepper (2007). The need of a serious study of Jewish criminality was underscored by Samuel (1981). 
East London is sufficient to indicate the possibility of significant variation in policeminority relations. It suggests, too, that, contrary to certain trends in recent police historiography, a community-centred comparative approach with an emphasis upon the social situation and material circumstances of minority populations, is likely to prove more rewarding than is sometimes imagined.

\section{GROWTH OF THE GHETTO}

'Whitechapel', declared a report of 1884 , 'has never thoroughly recovered from the overcrowding that arose when, night after night, wagon-loads of poor Jews were brought up from the docks, where they had just arrived, still panic-stricken, from Russia $^{98}$. And it never did recover. The forces that set the wagons rolling at the beginning of the 1880s drove with ever greater fury in the years that followed. The wagons were busy in 1886 to convey the influx that following the expulsion of the Poles from Prussia. They rolled even more hectically in 1891-1892 after the mass expulsions from Moscow and Kiev. They were at their busiest, however, after the Kishinev pogrom of 1903 and the Russo-Japanese War of $1904^{9}$. East London was transformed. The new arrivals, settling in the streets adjoining the traditional Jewish area of settlement on the eastern boundaries of the City, soon constituted a solid block that extended from Aldgate through Houndsditch and Middlesex Street to Commercial Street. To the north of the Whitechapel Road, the movement was eastwards from Spitalfields to Mile End New Town. 'The newcomers', said a contemporary description, 'have gradually replaced the English population in whole districts which were formerly outside the Jewish quarter. Formerly in Whitechapel, Commercial Street roughly divided the Jewish haunts of Petticoat Lane and Goulston Street from the rougher English quarter lying to the east. Now the Jews have flowed across this line; Hanbury Street, Fashion Street, Pelham Street, Booth Street, Old Montague Street and many other streets and lanes and alleys have fallen before them; they fill blocks of model dwellings... and they live and crowd together, and work and meet their fate almost independent of the great stream of London life surging around them ${ }^{10}$. Thereafter the immigrant settlers began to fan out, moving along an arc that stretched southwards through Whitechapel, took in the western tip of Mile End Old Town, and extended down the north-western portion of St George's-in-the East.

'It is not difficult to recognise the Jews', Booth remarked: 'the School Board visitors know them well ${ }^{11}$. Their poverty was their most obvious characteristic. The School Board Visitors, who provided much of the evidence for the Life and Labour Inquiry, gave graphic accounts of the immigrant condition. Buckle Street, Whitechapel, for example, they reported as packed with Polish Jews - 'they are shut in here' said visitor Golding. It was 'a very poor and crowded place' full of half-clad women standing about on the landings. 'Still', he added, 'it is a better place than Plough Buildings'. The latter was indeed the pits, 'filthy to the last degree', 'a working model

8 Report of the Lancet Special Sanitary Commission on the Polish Colony of Jew Tailors, The Lancet, 3 May 1884, pp. 817-818.

9 The pattern of immigration is well described in Lipman (1954); Gartner (1973).

10 Booth (1902, Poverty, III, pp. 103-104).

11 Booth (1887, p. 45). 
of Jerusalem - a fearful place'12. The diet of these 'poor class Polish Jews' was equally wretched. 'This class', said Mr Bowsher, 'usually live on specked potatoes, stale bread, wurst (a kind of sausage), bagles (a light kind of bread), wh. [sic] they soak in soup made up of the coarsest parts of animals, stale or decayed fish, i.e. they have very little 'legitimate' food ${ }^{13}$. Corroboration came readily from clergy and doctors. The Rev. Walter Bourchier of St Olave's, Hanbury Street, for example, gave 'a terrible account of the filth and insanitary habits of his Jewish parishioners'. Indeed, so intolerable was the neighbourhood that, for the sake of his wife and children, he had quit the vicarage and taken a house outside the parish ${ }^{14}$. Booth, in his pilot study of Tower Hamlets, classified 75 per cent of Jews as 'quite poor' or moderately poor' ${ }^{15}$ In the ten years that followed, the conditions in which they lived seem to have improved but little. 'Some of the people even sleep on the landings', said a London City Missionary of one block of dwellings crowded with Polish Jews ${ }^{16}$. 'The Jews', a colleague concluded'... give a lower tone... to the streets they enter'. ${ }^{17}$

Their poverty, though, was not of the ragged variety common on the streets of East London. The Jewish immigrant looked different. Sources of differentiation were highly visible. Along the Whitechapel Road, wrote Llewellyn Smith, 'the observant wanderer may note the high cheek-bones and thickened lips of the Russian or Polish Jew, [and] the darker complexion and unmistakable nose of his Austrian co-religionist.' The women with their 'olive complexions' and 'dark-bearded men in Russian-Polish dress' seemed exotic and mysterious by comparison with their ill-clad contemporaries from Ireland or the equally drab English. Religious requirements further demarcated the immigrant and native populations. The mezuzah displayed on the doorpost of every house, a contemporary noted, was 'one of the first things which struck my notice'. Equally memorable was the sheitel, 'the ugly brown wig' worn by Orthodox married women, or the vigilant shomer policing the butchers of Wentworth Street to ensure compliance with the dietary laws ${ }^{18}$. Then there were the proliferating synagogues and the processions and celebrations at festivals like Purim or Simchat Torah, the sombre promenading at Rosh Hashanah and Yom Kippur and the sedate Sabbath closure which also set the immigrant community apart from the metropolitan mainstream.

Judaism, though central to the identity of the immigrant, did not enjoy an uncontested hegemony in the area of settlement. The newcomers created an assertive ethnically-based popular culture which still awaits its historian. Self-generated institutions were numerous. The friendly societies movement was respectable. The same could not be said of the various clubs, meeting halls, trade union branches and coffee shops that sprung up. Some were barely disguised gambling dens; others combined politics with entertainment. The pious condemned them; the police were vigilant ${ }^{19}$.

\footnotetext{
12 TBC: B9/ 22-22, 25.

13 TBC: $: \mathrm{B} 8 / 70$.

14 TBC: B221/ 51-53.

15 Booth (1887, p. 49).

16 TBC: B223/97.

17 TBC: B 175/ 21-22.

18 Booth (Poverty, 1902, III. pp. 100 and 104); Brewer (1892, pp. 16-20 and 119-123).

19 Petrow (1994, p. 207); TNA HO 45/10819/318095/529. Special Branch report on Russian Revolutionary Matters, 3 January 1918.
} 
Sometimes religious and secular cultures were too close for comfort. The policing difficulties of the district were on occasion aggravated by disturbances due to the conflict between the secular and the spiritual. The quarrelsomeness of the immigrants, a standard feature of police observation, though generally rooted in personal and domestic issues, was also sustained by the struggle between religion and politics. The baiting of the shul, a regular sport among East End Jewish radicals, scandalised the Orthodox community and sometimes provoked disorder. The worst of such incidents occurred in the afternoon of Yom Kippur 1904, when a body of socialist atheists drove a van containing food through streets filled with fasting Jews. This was too much. Stones were thrown, bottles followed. Commotion spread. Within half an hour Brick Lane and Princelet Street were in 'a state of great agitation'. Large bodies of police from every station in $\mathrm{H}$ Division were quickly drafted to the scene of the disturbance. Arrests were made, the streets cleared and the area cordoned off. Order was restored by 10.00 p.m. when the police, tired and doubtlessly perplexed, withdrew ${ }^{20}$. Jewish immigrants, though, were not only strange in their clothing and conduct. Their language was equally puzzling. It was the language of the immigrants which defined the area of Jewish settlement and created the initial impression of being in some distant territory. Shopkeepers with unpronounceable names selling goods advertised in an incomprehensible language, and above all the locals 'gabbling in an unknown tongue' made for a sense of isolation and curiosity. 'But for the street architecture', an honourable member remarked, 'one might easily imagine the place to be the busy quarter of an Eastern town' ${ }^{21}$. Bobbies on the beat endorsed the sentiment. Misunderstanding, conflict and consternation were unavoidable where English was neither spoken nor understood. A Polish girl who got lost and became confused was taken by the police to an asylum for the insane; a rabbi who went to a register office to make enquiries was married by mistake and had to seek an annulment $^{22}$ ! Effective policing too was impossible where the people spoke little English and the police spoke nothing else. The want of Yiddish, however, was not just a bar to routine police administration; it also impeded the investigation of political deviants. Superintendent Mulvaney, head of $\mathrm{H}$ (Whitechapel) Division, stated in 1904: 'Bills and circulars in this language are distributed and posted all over the division, but police know nothing of their purport unless an interpreter is employed to translate them. As it is known that a number of these people are members of Continental Revolutionary Societies it would be very desirable to have members of the Service who could speak this language'. The Home Office agreed and a modest scheme was initiated to create a cadre of Yiddish-speaking constables ${ }^{23}$.

The alien presence aroused strong feelings in East London. Tension between the immigrant and indigenous populations arose over housing and jobs, life-styles and language. It sustained a deep-rooted anti-Semitism that began in the school

20 The Times, 20 September 1904. See also Fishman (1973, pp. 259-261).

21 TBC, Correspondence \& Reports, A23/ 92, report of Harold Hardy on London Costermongers and their Markets; Select Committee on Emigration and Immigration (Foreigners), qq. 2829-2830.

22 Report of the Jewish Association for the Protection of Girls and Women, London, (1901, pp. 70-71); TNA RG 48/301. Beth Din to Whitechapel Register Office, 1 April 1925; The Law Times, (1926, 162, pp. 360-362).

23 See TNA Mepo 2/733. 
playground and spilled onto the streets. Jew-baiting and Jew-beatings were common $^{24}$. For some it was a source of pleasure, for others a source of defence. The disruption of the housing market consequent upon rapid immigration caused dismay and despair. Pressure on accommodation, leading to rising rents and increased overcrowding, provoked agitation and unrest. In some streets a Judenhetze prevailed ${ }^{25}$. Immigrants also encountered opposition in the labour market. The absence of Jewish employment from the port transport industry, noted by Ben Tillet in evidence before the Select Committee on Sweating, owed much to violence and intimidation. 'If a Jew gets work at the Docks,' a contemporary observed, 'he is so jeered and chaffed that he is obliged to give it up.' Others, it was claimed, were compelled to take up tailoring as English employers as rule have a 'moral antipathy to employing Jews ${ }^{26}$. Those in the garment trade found the competition fearful. The impoverished homeworkers, who were interviewed by Booth or his associates in 1888, were deeply resentful. Mrs Lee, a tailoress of 50 James Place, Devonport Street, Commercial Road, 'spoke bitterly of the Jews... When you go to the warehouse they are there, a whole row of them, ready to take everything.' But it was their depressing effect upon earnings that so infuriated Mrs Goodey, a trouser machinist, when interviewed in her home at 46 Wilson Street, Stepney. 'The Jews had caused the fall in prices,' she grumbled, 'every time the work comes in they take a $1 / 2 \mathrm{~d}$. or $1 \mathrm{~d}$. off the price ${ }^{27}$. Others called for action and not words: 'If we broke the heads of fifty Jews down here in Whitechapel', said one irate workman, 'something would be done to prevent this immigration'28.

Shopkeepers and costermongers were also hostile. Apart from weekday competition, they suspected that minority claims for Sunday opening were nothing but a cunning attempt to create a Jewish trading monopoly. Others condemned Sunday trading as being anti-Christian and anti-social ${ }^{29}$. The clergy, overwhelmed by the displacement of the church-going population, were particularly critical. "The changes,' said the Minister of Commercial Road Baptist Church, 'have been as sudden as if the good ship of the church had encountered a cyclone ${ }^{30}$. The Revd. Walter Bourchier, a one-time Fellow of New College, Oxford, who came to Mile End New Town in 1886, considered his ministry superfluous and himself redundant. 'Of a population of some 6,000 ,' he told one of Booth's associates, 'only 600 Gentiles' ${ }^{31}$. The Revd. George Bennett of St John's, Commercial Road, feared for the future of Christianity. The Wesleyan Chapel in Cannon Street Road, he explained, had been turned into a synagogue 'and holds a thousand or more,' while at a nearby chapel in Cable Street when once 'you could not get a seat, now you can get a galler' 32 .

24 On anti-Semitism in playground, see Goldberg (1937, pp. 3-4). On assaults on Jews, see evidence of Superintendant Thomas Arnold of H Division, Select Committee on Emigration and Immigration (Foreigners), qq. 875-909.

25 Englander (1983, pp. 120-121).

26 Select Committee on Sweating; Stallard (1867, pp. 8-9); Dyche (1898, pp. 35, 46).

27 TBC: A19/ os. 101, 115.

28 British Weekly, 25 May 1888.

29 The arguments for and against these positions were rehearsed at length before the Select Committee on Sunday Trading, 1905.

30 TBC: B224/ 51.

31 TBC: B221/ 51.

32 TBC: B000 (reference misplaced). 


\section{POLICE AND PEOPLE}

Policing, too, was strongly influenced by public concerns arising from Jewish concentration in the heart of the Empire. In this, as in other areas, the police often acted as a surrogate civil service, collecting evidence on social problems, asserting a certain expertise in selected areas and offering counsel and advice - sometimes unsolicited - to policy makers. Jewish immigration thus made considerable demands upon police resources. The movement of migrants from the East of Europe to the East of London was monitored by officers who were frequently required to brief legislators or report to the many committees and commissions that investigated the resultant social and economic consequences. Questions of poverty, crowding, crime, industrial displacement and insanitary conditions defined the scope of police observation. The westward movement of Russo-Polish Jews was readily located within a push-pull framework in which the relative importance of spontaneous flight and systematic settlement was scrutinised and the place of chain migration noted. The police presentation also included a description and evaluation of their effect on the labour and housing markets with comments on the customs and pastimes of the newcomers, their propensity to crime - as victims as well as perpetrators - and a general assessment of their moral worth ${ }^{33}$. The recognition of police evidence as a significant source of social observation, however, extended beyond the corridors of Whitehall and Westminster. Charles Booth, like Charles Dickens before him, valued the police not only for their protection, but also for their opinions and local expertise and sought their assistance in connection with his inquiry into the Life and Labour of the People in London. With the consent of Police Commissioner Sir Edward Bradford, 'experienced members of the police force, chosen for their local knowledge,' were assigned to the Booth Inquiry in connection with the revision of the Descriptive Map of London Poverty ${ }^{34}$. For this purpose the Metropolis was parcelled out into a number of beats each of them patrolled conjointly by interviewer and respondent. Nearly every street in London was visited and its social composition recorded. In H Division Booth and his associates enjoyed the company and cooperation of Inspector Reid, Sergeant French, and Superintendent Mulvaney. Not only were policemen required to identify so called Jewish streets, they also presented much incidental information about the character of the community. 'During these walks', wrote Booth, 'almost every social influence was discussed, and especially those bearing upon vice and crime, drunkenness and disorder ${ }^{35}$.

How representative are such sources? Bobbies on the beat have left few records. Station records, too, are rare and incomplete ${ }^{36}$. Studies of the social composition of the police labour force do, however, suggest that, in terms of class origins, the Metropolitan Police were close to those whom they policed. Policemen, it has been shown, were drawn overwhelmingly from the unskilled and semi-skilled working

33 See, for example, TNA Mepo 2/260. Report on Immigration of Foreigners, 26 July 1888. Police evidence was also submitted to the Royal Commission on the Housing of the Working Classes, 1884-1885 and the Select Committee on Sweating.

Booth (1902, Religious Influences, 1, pp. 6-7).

Booth (Final Volume, 1903, p.136).

36 Station records from Whitechapel, Hackney and Bow are either missing or not preserved. The most comprehensive listing is in Bridgeman and Emsley (1989). 
class $^{37}$. The fact that police service recruitment, at least up to divisional level, was based on a single-tier entry system, not only meant that lines of authority at work did not follow social class divisions, as in the military, but that serving officers had a close understanding of the realities of low visibility policing. Booth's investigators, though sceptical of much that was said, had no grounds for thinking that police observation was rank-related or distorted by social class. And neither have we. The information given to the Booth Inquiry is probably as representative of police attitudes and opinion as we are likely to obtain.

The police and public order perspective reflected the origins of the Life and Labour inquiry in the social crisis of the 1880s. Booth in his preliminary survey of the East End Jewish settlement had noted and discounted the prospects of political violence from this quarter. 'These foreign Jews,' he observed, 'are straight from the pressure of grinding despotism; some may add nihilism and the bitterest kind of socialistic theories to very filthy habits; but the meek and patient endurance with which they live their hard lives, and their ready obedience to the law, do not suggest any immediate fear of violent revolutionary activity on their part' ${ }^{38}$. East Enders themselves sometimes saw the immigrants as dangerous subversives ${ }^{39}$. Police observation, though, tended in general to support Booth's initial assessment. 'Polish Jews and Russians who come here are mostly strong socialists', said one informant. 'Their first inclination on coming over here and finding their liberty is to break out', but, he added, 'they don't do it long, ${ }^{40}$.

Jewish disorder, such as it was, owed more to poverty than to politics, and to the intolerable pressures which arose when, from time to time, the volume of immigration exceeded the absorptive capacities of Jewish philanthropy. The mass migration triggered by the Russo-Japanese War was one such moment. In East London, where the level of destination rose dramatically, police patrols reported 'hundreds of these people arriving and walking about practically without means of any sort'. Desperation on this occasion led to disturbance. At 12.30 p.m. on 5 December 1904, a crowd, estimated at 300 persons, assembled outside the Great Synagogue, Spitalfields, and threatened to force the doors when their demand for relief were refused. Prompt police action dispersed the protesters whose re-assembly was prevented by the maintenance of a strong police presence at Fournier Street and at the neighbouring synagogue in Booth Street $^{41}$. Such outbursts were exceptional. The leaders of Anglo-Jewry, acutely conscious of the damaging effects of disorderly conduct, sought not only to assist those who would accept voluntary repatriation, but also to develop an extensive support network for the socialisation of those who were determined to stay. On the whole they were remarkably successful. Jewish disorder, sporadic and easily suppressed, never assumed a stereotypical character comparable with that of the fighting Irish.

Jewish criminality sustained a rather different stereotype, that of the 'foreign bully', a dangerous degenerate who trafficked in white slavery and was closely con-

37 Shpayer-Makov (2002); Emsley, Clapson (1994).

38 Booth (1887, p. 48).

39 Royal Commission on Alien Immigration, 1903, p. 9 and qq. 399-402, 2934-2943, 2977 2982, and 5362-5400.

40 TBC: B350/ 45.

41 TNA Mepo 2/260. Report by Inspector J. Hewison, Commercial Road Police Station, 5 December 1904. 
nected with the 'criminal alien', a specialist in political subversion, who threatened the moral and racial health of the nation ${ }^{42}$. Policemen on the beat, though, were not unduly alarmed. The Jewish community was said to produce criminals, but no criminal classes ${ }^{43}$. Petty and irksome, Jewish crime was not considered unmanageable. The lodging houses in Gun Street 'where the Jew thieves congregate' were all known to the police ${ }^{44}$, as were their gaming houses - 'Jews gamble rather than bet' Even juvenile crime, a serious problem, was perceived as an age-specific rather than a permanent condition, unlike the native variant. As one policeman put it: 'they seldom get an old Jew as a thief - with the Englishman once a thief always a thief' ${ }^{46}$. Jewish criminality, in short, was containable. The more serious threat to public order came from inter-communal conflict; from the goy rather than the gunov.

Problems of peace-keeping inevitably directed police attention towards the process of ghetto formation. Booth himself likened the coming of the Jews to the slow rising of a flood ${ }^{47}$. Police observation, however, presented the growth of the ghetto not as the natural or irresistible outcome of foreign immigration, but as a negotiated process. The assertion of Jewish territoriality was contested street by street by an indigenous population that was alarmed by the inflationary influx on rented accommodation ${ }^{48}$. Peace reigned only in those streets in which the issue had been decided; where native and immigrant lived side by side, uncertainty persisted with 'friction and quarrels the inevitable results' ${ }^{49}$. In streets colonised by Jewish and Irish immigrants tensions ran high. Thus Duke Street and Black Lion Yard, with their mixed populations, were both considered dangerous while Spring Gardens, with its mixture of poor Jews and Irish, was said to be 'a rough place for the police' ${ }^{50}$. The trend, though, was towards complete segregation; streets tended 'to become all Jew or remain all English' ${ }^{51}$.

Street supremacy, once established, was not usually subject to further challenge. Only very occasionally were the victors vanquished. Shepherd Street, where 'the Jews have been turned out by a set of rough English and Irish', was one of the few streets to have changed hands twice ${ }^{52}$. In general, the non-Jewish population, indigenous and immigrant, appears to have relied upon intimidation without combination to prevent Jewish settlement. Spontaneous collective violence to prevent Jewish settlement was rife in frontier streets where the contest for territoriality was most intense. The existence of exclusion zones, which Jews entered at their peril, was acknowledged by the police. The Boundary Street area, following the clearances of

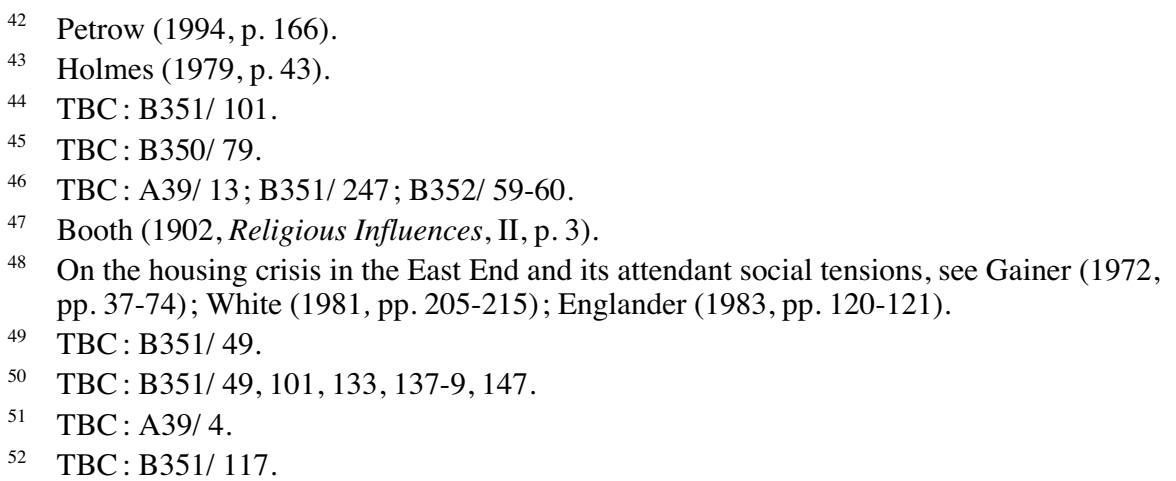


the slums around Old Nichol Street [district fictionalised as the Jago], was one such quarter. 'No Jews have their foot as yet in this district,' said Sergeant Trench. 'They would not dare to, they would be so roughly handled ${ }^{\prime 53}$. The area bounded by Balls Pond Road on the north and the Regent's Canal on the south was likewise said to be 'singularly free of Jews'. 'The people will not neighbour with the Jews', a local policeman explained ${ }^{54}$. The prospect of having their heads kicked in also kept Jews from settling in certain riverside districts ${ }^{55}$.

Police perceptions were conditioned partly by prejudice and partly by professional self-interest. 'On the whole', said Superintendent Mulvaney, the immigrants were 'not rough towards the police'. 'They knife one another but not those in authority ${ }^{56}$. The newcomers, though submissive and respectful, were a nuisance - 'dirty, messy and great cheats', said Inspector Drew of Stepney Green; 'they bring their private quarrels to the police station each charging the other with crimes. It is impossible to believe either' ${ }^{57}$. Englishmen', said a colleague, 'were rougher but the Jew more tricky', a statement lent support by Judge Montague Williams whose dictum, 'A Jew never tells the truth except by mistake', was cited by police officers with approbation $^{58}$.

The social origins of the police, their pay and the considerable job autonomy enjoyed by front line officers, gave the man on patrol a craft conception of his work. The scope of police work in consequence owed less to external control and more to the policeman's perception of his working environment. Essentially an artisanal profession, the police force shared the prejudices of the people it policed. To the eye of the respectable Englishman, the newcomers, though not wanting in decency or discipline, appeared to live in dirt and disorder. Streets, strewn with decomposing fishheads and fruit, or lines with litter and rotting vegetation, were automatically classified as 'Jewish' as though there was some necessary connection between faith and filth ${ }^{59}$. Cleanliness was immaterial. 'Jew children', said Inspector Drew, 'are always messy ${ }^{60}$. The state of the windows, condition of curtains, fixtures and flowers, also advertised the Jewish presence. Clean curtains, tidy blinds, wax flowers, fruits displayed under a class case in the front window - these, the signifiers of respectability, were significant absences from Jewish homes ${ }^{61}$.

But if not respectable, Jews were not rough. It was the singularity of Jewish culture and customs that was most striking. The newcomers, though quarrelsome and noisy, were essentially private people not much given to brawling and boozing or the lower forms of street life. Their home-centredness found expression in the attention lavished upon children, in the rarity of wife-beating and in their generally orderly

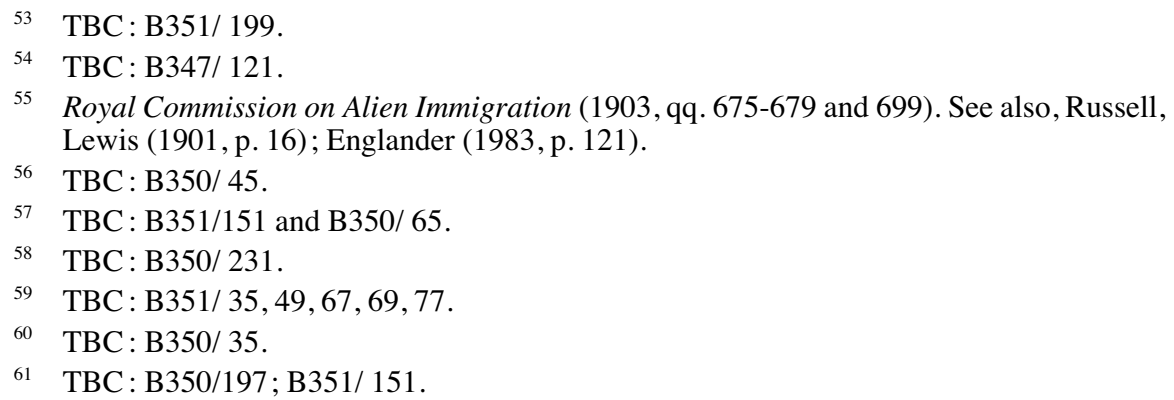


conduct. The 'Jewish type' of child, said Inspector Reid, was fairly dressed, clean, well-fed and booted ${ }^{62}$. 'Jews rarely get drunk', said Inspector Barker, his colleague from the Bethnal green Division. 'Jew women as a rule lead happier lives than Gentile women, more respected by the husband and more faithful' ${ }^{63}$. Jews, in short, did not fit easily into the language of class.

The exclusive character of immigrant pastimes accentuated Jewish separatism and left the bobby on the beat more bewildered than ever. 'Jews drink very little in the public houses', so Duckworth was informed; 'the police cannot understand them at all. They shut themselves up in their clubs and there is no getting at them ${ }^{64}$. Part of the difficulty was linguistic. Members of the Met were not on the whole Yiddishspeaking while those whom they policed often spoke nothing else ${ }^{65}$. For the puzzled policeman the sense of incomprehension was further deepened by the distinctive garb of the ghetto. The men with their dark beards, fur caps and long boots; the women, bareheaded, bewigged, their coarse woollen shawls draped over their shoulders, made both Inspector Reid and Sergeant Trench feel as though they were present in a foreign town ${ }^{66}$.

Immigrant Jews, it seemed, lived within English society but were not part of it. The fact that they were neither rough nor respectable; that they appeared clean in person but dirty in habits, or that they possessed middle class virtues but lower class values, made their location within the class structure exceptionally difficult to determine. The growth of the ghetto and the transitory status of streets affected thereby compounded the problem. Booth's policemen hesitated to assign 'Jewish' streets an appropriate class colour on the 'Poverty Map ${ }^{\text {'67 }}$. Inspector Drew, Duckworth noted, had 'great difficulty in distinguishing between streets that shd. [sic] be purple and those that should be pink'. Drew's uncertainties reflected a discrepancy in the appearance of the houses and the character of the people. 'As far as outward appearances are concerned', the police officer observed, 'nearly all the streets belonged to the "pink" category'. The interiors, however, raised doubts. 'In the Jewish ho. [sic]', he explained, "with its greater crowding there is no china pot with an evergreen plant in the front window on a round table which in North London used to be the sure mark of a "pink" character. Again there is greater visible dirt in a fairly well-to-do working-class Jewish house than in an English one ${ }^{68}$. Drew's confusion was shared by his colleagues. 'Again difficulty of telling by appearance whether some of the small Jew streets should be pink, purple or light blue' Duckworth wrote of another police informant. A further entry in the same notebook records the recurrent problem respecting the colour classification of streets in process of Judaization. 'Seemingly a great mixture of well to do, poor and very poor in adjacent houses or even in the same house, among Jews than among Gentiles ${ }^{, 69}$.

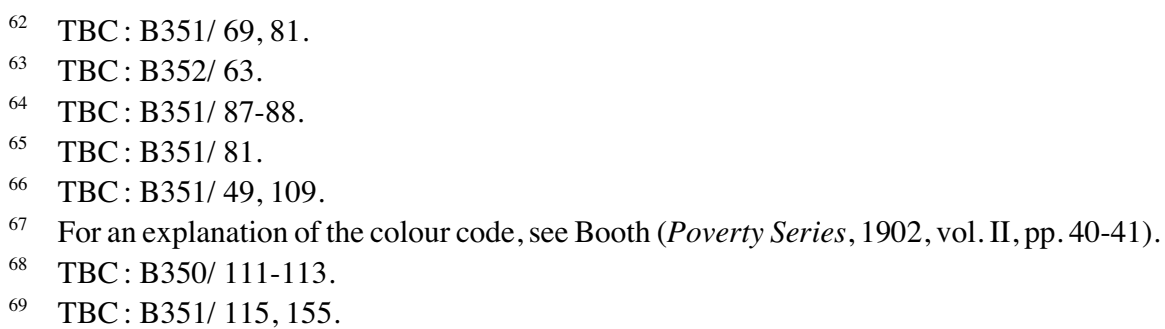


The pace of embourgeoisement compounded the difficulty. The uncertain status of immigrant Jewry and its location within the class structure in part reflected the extraordinary rate of social mobility within the Jewish community. The movement from 'greener' to 'gov'nor', and from Whitechapel to Willesden, was, indeed, upheld by Beatrice Potter as proof of the essentially progressive character of the Jewish race. The yeasty properties of the people, signified by their departure for the smart suburbs, was subsequently confirmed by both police and clergy. The upwardly mobile East Enders travelled North by North-West along a well-charted course that took them through Victoria Park, Highbury New Park - "Highbury Jew Park" Baxter calls it ${ }^{, 70}$ - Dalston, Stoke Newington and Clapton terminating, for the most successful, at Hampstead or London West Central. 'It takes three generations to get from Whitechapel to Kensington', said a Congregationalist minister, 'Hackney is the first step" ${ }^{71}$. Of Dalston, a police informant said, 'It is the intermediate stage of their march from Whitechapel to Hampstead"72. At Shackewell Lane, Duckworth espied a former tally tailor, now gone up in the world, who seemed to personify the process. 'Round the green was driving a Jew smoking a cigar with his wife by his side, a servant in livery with cocked in his hat behind'. In nearby Sandringham Road with its smart three-and-a-half-storeyed houses, the state of the gardens advertised the Jewish presence: 'in none of them', Duckworth was told, 'were there any signs of care or order or flowers, ${ }^{73}$.

\section{MINORITY LEADERS AND POLICE MANAGEMENT STRATEGIES}

The tendency of police observation to distance the constabulary from the community requires further consideration. Two features are particularly noteworthy. The first involves management strategies of the minority population and the organizational objectives of the police. The second concerns the nature of everyday policepublic relations in Jewish East London. The latter is relatively straightforward. The scope for interaction between policemen and the local community, though no doubt restricted, was not quite as negligible as contemporaries sometimes suggested. Policemen after all lived among the people they policed. The nature of the social relations that existed in East London and the place of the immigrant in the canteen culture of H Division would no doubt bear closer scrutiny. Booth and his associates certainly thought so. Police informants were readily pressed on the irregular and possibly corrupt connections that were rumoured to exist in the police service particularly in relation to publicans and pay-offs, gambling and graft, brothel-keepers and bribery. Police respondents naturally denied any impropriety. East Enders, with long memories, thought otherwise. One of them, with an exceptionally close knowledge of the local constabulary, recalled how Jewish gambling clubs off the Commercial Road prospered by bribing police officers and consent to regular arrests ${ }^{74}$. Such

\footnotetext{
70 TBC: B348/167.

71 TBC: B $187 / 37$.

72 TBC: $\mathrm{B} 347 / 97$.

73 TBC: B347/ 85, 89.

74 Samuel (1981, pp. 203, 327).
} 
conduct was not, however, specifically related to the immigrant community. Historians now believe that extra-legal relation of this sort were not an exceptional, but a necessary feature of normal policing ${ }^{75}$.

Questions concerning police management strategies in the immigrant quarter are more complicated. Police historians have in recent years drawn attention to the importance of individuals and groups who dominate informal networks of power and influence within the minority in the maintenance of order. Jennifer Davies in a comparative study of the Irish in mid-nineteenth-century Kensington and late-twentieth century Tottenham has argued that it was the presence or absence of collaborative arrangements with immigrant leaders which determined public order in what were otherwise no-go areas ${ }^{76}$. Her account, valuable though it is in highlighting the dynamics of policing immigrant minorities, is not applicable throughout London. In the first place it assumes that relations between the two parties are antagonistic and characterised by endemic violence; in the second, it assumes an immigrant leadership recruited from low social status power brokers who were ready to perform the managerial roles prescribed by the police. Neither assumption is valid in respect of Jewish East London. Police understanding was no doubt affected by the action-man ideology of the bobby on the beat and the stereotypical images which he shared with the public towards the immigrant minority. But, as Booth's investigators discovered, policemen were flummoxed by the improving character of the newcomers, their beneficial role as 'moral scavengers' and their uncertain location in the class structure. Jewish communal leadership was equally important. The want of an effective middle class serves to separate the Irish and Black experience in Britain from that of the Jewish minority. The presence of a long-settled, mercantile, financial and professional native elite which claimed to speak on behalf of immigrants from RussoPoland affected the situation in H Division. Jewish communal leadership, though it represented a valuable management resource on which the police authorities could readily draw, differed in its wealth, social standing and organisation from that available in Jenning's Buildings and the variant Irish colonies that were scattered through the Metropolis. Moreover, whereas English Catholics preferred to distance themselves from their immigrant co-religionists, Anglo-Jewry felt that inaction threatened to disrupt the delicate balance that existed between the minority and majority populations. The police in Whitechapel were in consequence more likely to be the objects rather than the agents of manipulation by minority leaders who viewed the socialisation of their co-religionists from the East as an essential priority and a public service.

The reconstruction of the Jewish community during the Queen's reign and the centralisation of lay and ecclesiastical authority were largely the work of an acculturated cousinhood of bankers and brokers who controlled communal resources.

It was this aristocracy of finance who supplied the leadership of 'The Jewish Board of Guardians' and of 'The Board of Deputies of British Jews' and gave direction to the Chief Rabbi and the United Synagogue. Its aims, broadly speaking, were to safeguard the rights and privileges which the minority had obtained, prevent civil and religious discrimination and promote social betterment through the incorporation

75 See, for example, Dixon (1991); Petrow (1994).

76 Davis (1989). 
of the Jewish poor within an enlarged and prosperous class ${ }^{77}$. The civil authority, though it took no direct part in the management of the minority, was supportive. 'The Board of Deputies' was the recognised intermediary between the state and the Jews; the Chief Rabbi, too, enjoyed a special relationship. Questions concerning the status of marriage or the validity of a divorce, particularly among Jews of foreign extraction, were by arrangement referred to the Chief Rabbi and his Court. The Registrar-General, the police and the civil courts were pleased to accept rabbinical guidance in these matters. Indeed, Jewish litigants in the civil courts were often advised to seek the adjudication of the Beth $\operatorname{Din}^{78}$. The Jewish authorities were equally co-operative in respect of the regulation of the immigration process and the immigrant poor.

The general strategy of the Anglo-Jewish leadership was to discourage permanent settlement, but at the same time to initiate measures so that those who chose to stay did not become a burden on the public purse or bring the established community into disrepute. Pressure from the Jewish community led to improvements in the policing of the ports and prevention of fraud at the quayside. Homeless arrivals were by arrangement escorted by members of the Met to the offices of 'The Jewish Board of Guardians' for appropriate action. Allegations of assault and mistreatment of passengers were taken up and legal assistance provided to secure a conviction where it was felt that there was a case to answer. Police performance in pursuit of these and similar prosecutions was carefully monitored ${ }^{79}$.

The disruptive effects of immigration on family relationships, its malign influence on manners and morals, and the presumed causal connection with vice and criminality, were matters of the gravest concern. Wife-desertion and wife-beating, child abuse, gambling, poncing and brothel-keeping, were all viewed as regrettable effects of the too rapid inflow of migrants from the disturbed communities in Eastern Europe. Native Jewish leaders were ready to initiate or support fresh coercive legislation or mobilise police and judiciary in order to extirpate the immorality that threatened both the national well-being and the good reputation of its most loyal minority ${ }^{80}$. In the years before the First World War, 'The Board of Deputies of British Jews', 'The Jewish Association for the Protection of Girls and Women' and other purity groups worked together to prepare legislation and advice for the last Liberal Government ${ }^{81}$. While some worked the corridors of Whitehall, others worked the streets of $\mathrm{H}$ Division. 'The Ladies Visiting Committee of the Jewish Board of Guardians', for example, often adopted a pathfinder role identifying unsatisfactory houses for police action; and where the evidence obtained was deemed to be insufficient, the Board promised to supply more ${ }^{82}$. Jewish vigilance groups indeed acted as a moral police, imposing themselves upon their recalcitrant co-reli-

77 On the nature of Jewish communal leadership, see Englander (1988).

78 See RG 48/213; Israel Cohen; Nettie Adler.

79 HL, Minutes of the Jewish Association for the Protection of Girls, Women and Children, 30 March 1891, fos. 89-90.

80 See Bristow (1982).

81 See TNA Mepo 2/1529 and Bristow (1982, p. 164).

82 HL: Minutes of Jewish Association for Protection of Women, Girls and Children, 3 May 1896, fo. 156. 
gionists in the name of order and decency ${ }^{83}$. But it was not only the vicious and immoral elements who were kept under close surveillance. The police themselves were also a target. 'The Ladies Committee of the Jewish Board of Guardians' included redoubtable figures like Constance Rothschild (Lady Battersea), whose attempts to mobilise extra protection for women at risk, whether from violent spouses or white slavers, kept divisional chiefs and the commissioner himself on the alert ${ }^{84}$.

The close collaborative arrangements that existed between the police and local judiciary and the minority's lay and ecclesiastical leaders were mutually advantageous. It made for good community relations and the maintenance of public order. The police found sympathy and support from the Jewish authorities who in return received practical assistance in matters that sometimes had as much to do with communal management as with any presumed violations of the law. Police involvement in the monitoring of irregular marriages among immigrants is a case in point ${ }^{85}$.

Marriages solemnized by immigrant rabbis who did not acknowledge the authority of the Chief Rabbi, though perfectly valid in Jewish law, were an affront to the leaders of Anglo-Jewry. The Chief Rabbi who used his privileged position in the marriage registration process to bolster his own status, claimed that these unsupervised foreign rabbis were creating a major social problem; lay leaders associated clandestine weddings with white slavery and family instability. Police cooperation was sought for coercive legislation that would make the solmenization of such unions a felony. But for the First World War, however, these efforts would have come to nothing ${ }^{86}$.

\section{WAR, MARRIAGE AND INTERNAL MIGRATION CONTROL}

The potential for conflict and disturbance, always high in an impoverished and ethnically-mixed district became acute in times of crisis. The Ripper Murders are good illustration. Anti-Semitic fantasies, orchestrated by a sensationalist and irresponsible press, led to harassment and street violence. The local police, who shared popular prejudices and encouraged their outward expression, soon became alarmed at the growth of anti-Jewish disturbances. In September 1888, following the discovery of the second victim, Whitechapel was swamped with reinforcements in order to prevent the outbreak of a full-scale pogrom ${ }^{87}$.

83 Mr. Lazarus, for example, was hounded ruthlessly before consenting to his two young daughters being taken into care in an industrial school, following his wife's conviction for theft: See HL: Minutes of Jewish Association for Protection of Women, Girls and Children, 3 \& 31 May 1896, fos. 156-158, 160.

84 On Lady Battersea and police representations, see HL: Minutes of Jewish Association for Protection of Women, Girls and Children, 31 May 1896, fo. 162. On domestic violence and assaults on Jewish women, ibid., 18 December 1892, fos. 119-122; also see ibid., 2 December 1894, fos. 136-137.

85 See HL : Minutes of Jewish Association for Protection of Women, Girls and Children, 15 December 1895 , fo. 149 .

86 On marriage reform and its ramification for minority-majority relations, see Englander (1992).

87 Fishman (1988, pp. 209-229); Walkowitz (1992, pp. 202-205). 
The vigilante impulses disclosed during the Whitechapel Murders, were but a harbinger of the much greater disturbances that were provoked by the national crisis that began in 1914. In the former the police had just about managed to restrain widespread disorder. The passions released by the latter were uncontainable ${ }^{88}$. On the eve of war foreigners in Stepney constituted 31.0 and 39.0 percent of the total male and female foreign population, enumerated in London. Between 1914 and 1918, 20,000 aliens were deported and 32,000 were interned. Most were males; some were married; many were Jews. Botched in its planning and execution, the arrest, release and subsequent detention of large numbers of foreign residents served to confuse and alarm the public and convince them that more direct measures were required for the defence of the realm.

Anti-German sentiments, a potent source of disorder in the first half of the war, were gradually supplanted by an equally virulent form of anti-Semitism. The shift was due primarily to conscription. The manpower crisis not only diminished police efficiency, it also raised fresh sources of disorder and unrest. Chief among them was the alien Jewish profiteer, who allegedly shirked military service as so to secure an unfair advantage over the indigenous population. There were approximately 25,000 to 30,000 male Russian subjects of military age, mostly of the Jewish faith, in British cities. Large numbers were either unwilling or unfit to serve in allied armies. The introduction of compulsory military service at the opening of 1916 made their position untenable. Increasingly the 'foreign Jew' was presented as a parasite and a predator, snatching the jobs and comforts of the indigenous population while Britannia's sons sacrificed all for freedom, democracy and decency. The Press railed against the base ingratitude of the immigrant hordes who enjoyed the privileges of life in Britain but refused to share the burdens. Punitive measures were called for. These saucy Semites, warned the East London Observer, were by their very presence an incitement to the native population. The Home Office, fearful that the continued immunity of the immigrants would lead to agitation and disturbance, took powers to deport or conscript the resistant Russians.

It did no good. The first signs of disorder came from Highton in Manchester, sparked by the casualties that followed the Somme offensive in 1916. Waterloo Road, situated between the mainly Jewish Strangeways district and the ethnicallymixed Hightown area, became a battleground where the larger conflict was reenacted by hooligan armies drawn from the non-Jewish and minority populations. That summer, crowds of youngsters, known as 'scuttlers' and later as the 'napoo gangs', crossed from Pemberton Street and Craven Street into Waterloo Road for what was the become a ritualised anniversary assault upon the Jewish residents of the area $^{89}$. Communal conflict in Leeds and London the following year displayed similar features. Once again young people were prominent in initiating the disorders, and once again the scene of the trouble was located on the boundaries between neighbourhoods where communal conflict was often most intense.

On 23 September 1917, immediately before Yom Kippur, street-fighting broke out on the fringe of the Jewish East End. Blythe Street and Teesdale Street, which ran parallel at right angles with the Bethnal Green Road and were occupied 'almost exclusively' by Russian Jews in the tailoring trades, were overrun by an angry mob.

88 An extended account of popular disorder in wartime will be found in Englander (1991).

89 Levine (1984, p. 6). 
The crowd, according to police estimates, numbered five thousand persons. The Jewish element, being outnumbered, retired indoors for safety. The windows of Jewish shops and houses were broken, and Jewish pedestrians insulted and beaten. The following day there was a recurrence of disorder with further stoning and broken windows.

The causes of the disturbance were uncertain. Press reports explained the outburst as the extension of a public house brawl between the splendid soldier and a foul-mouthed Russian Jew in which revolvers were brandished and shots fired. Soldiers were certainly involved. A crowd of about 200 persons assaulted three Russian Jewish soldiers who had been on leave for Yom Kippur and stoned the shop in which they had taken refuge. Among the assailants women and youths were conspicuous. The one arrest was of a sixteen year old carman. 'This youth', said Superintendent Best in his report of the disturbance 'seeing several men of Jewish appearance passing, said to some companions - 'There's another gang of $\mathrm{f}-\mathrm{-}_{-} \mathrm{g}$ Jews' and ran towards them, when he was at once taken into custody.' The authorities were on the whole keen to minimise the whole matter. The Metropolitan Police Commissioner denied that the incident was anything more than a street brawl. Home Office officials in confidence thought that the Russians Jews deserved all that they received. Not only were Jews creating trouble on the streets, their monitoring and surveillance added significantly to the wartime multiplication of police duties ${ }^{90}$.

The First World War marked a watershed in the relations between the immigrant minority and the State. The system of internal migration controls, which had its origins in the procedures governing denization and naturalization, was developed by the Aliens Act of 1905 and considerably extended after 1914. Aliens were henceforth required to be registered with the police, restricted to specific areas, denied the right to enter or leave the country, and liable to deportation. These measures, though not directed specifically against Jews, struck hard at a community with an overwhelming preponderance of immigrants from Eastern Europe. The Aliens Restrictions (Amendment) Act of 1919 made the situation more precarious. Previous restrictions were consolidated and further controls imposed. Aliens in consequence were not allowed to serve on juries and were forbidden on pain of punishment to promote industrial unrest. In 1920 and Order in Council extended the Home Secretary's powers to deport, on his own initiative, 'any alien whose presence was deemed not to be 'conducive to the public good'.

During the war, and in its aftermath, the alien population was perceived as a threat to national security and public order. Antagonisms between native and immigrant populations, intensified by the pressures of total war, led to civil commotion, agitation and unrest. Demands for more stringent supervision proved irresistible. Immigrant Jews, found themselves subject to registration, enumeration, classification and continual observation by the police and intelligence services. Their movements were monitored, their circumstances scrutinized, their opinions recorded, and their activities analysed. Special Branch opened fresh files on 'Jewish revolutionary matters' and the Home Office through the police established a window into the Whitechapel ghetto. Police officers with a command of Yiddish were in great demand. Sergeant Albers of Special Branch combed the Yiddish-language press with all the assiduity of a doctoral candidate. P.C. Greenberg developed the art of

90 Englander (1991, pp. 113-116). 
participant observation; he attended various meetings in plain clothes, and posed as an activist, committing the speeches and declarations of political dissidents to memory 'as any attempt to take shorthand or other notes would have brought my immediate ejectment ${ }^{91}$.

There was little privacy. Police were everywhere. Immigrant minorities were harassed and oppressed. The end of hostilities, though, brought no relief. The upsurge in anti-alienism in the post-war period was accompanied by expulsions of enemy aliens, many of them Jewish tailors who had spent the war engaged in the production of uniforms for British soldiers. The net of orders and restrictions in which those who were not naturalized were entrapped was more tightly drawn. Jews who failed to register a change of address made themselves liable to deportation. Those convicted of a minor offence might be deported on the say-so of a magistrate. There was no right of appeal. The mere fact of conviction was sufficient for the Home Office to proceed even if the court had not recommended deportation. Political activists were particularly vulnerable, but even harmless individuals who had lived in Britain for many years were at risk ${ }^{92}$.

Marital status and the verification of that status were critical features of the investigative process. Aliens, when registering with the police, were required to state when and where they had been married and to provide details of any children arising from the union. The reasons were twofold. Marital status not only affected nationality and therefore the rights of the individual; it also influences standards of conduct and was thus an important part of the character test which was used to separate the desirable from the undesirable alien. During the war, the registrar general and the ecclesiastical authorities were persuaded to collaborate with the Home Office in developing procedures to register changes in the marital status of the alien populations. Inter-departmental measures to prevent undesirable alien women from obtaining British nationality through marriage were revived during the 1920s. Immigrants who failed to supply full and accurate particulars were deemed to have committed a criminal offence. Many did so. Eastern European Jews who married or divorced without civil notice or ceremony were particularly vulnerable. The extent of these clandestine marriages, long regarded as an affront to the authority of the Jewish Establishment, now became a matter or public policy. The police, provoked by the temerity of a saucy whore, a Polish Jewess who had married an English Jew while awaiting deportation in order to flout police authority, initiated legislation which confused irregular with invalid marriages and so threatened the position of the immigrant community. The leaders of Anglo-Jewry, having formerly encouraged the police in this direction, now became thoroughly alarmed at the threat to the security of so many of their non-naturalised co-religionists. The police, so long accustomed to the badgering of communal leaders for coercive action against vice and depravity, found themselves on uncertain ground and gave way. The Jewish Marriages Bill was abandoned ${ }^{93}$.

91 TNA: HO 4510819/318095/84, Report of Sergeant Albers, 8 September 1916; TNA: HO 45/10819/318095/91, Report of P.C. Greenberg, Leman Street Station, 13 September 1916.

92 TNA: HO 4510819/318095/84. Report of Sergeant Albers, 8 September 1916; TNA: HO 45/10819/318095/91, Report of P.C. Greenberg, Leman Street Station, 13 September 1916.

93 See Englander (1992, pp. 100-104). 


\section{CONCLUSION}

Until the passage of the Aliens Act of 1905, there had been comparatively few points of contact between the police and the Jewish minority. Jews were generally considered sober and peaceable. Jewish criminality, if not negligible, was amenable to the extra-legal procedures that were part of normal policing and certainly not unmanageable. Apart from the innumerable disputes about trading regulations, prostitution, gambling and receiving were the offences with which the immigrant community was most readily associated. Crimes of violence were exceptional; policemen were not at risk in the ghetto. Police involvement with the Jewish community was affected as much by administrative arrangements as by considerations of crime. The naturalisation process, which required the police to test the literacy and moral worth of applicants for British citizenship, sometimes gave rise to claims of discrimination and police prejudice ${ }^{94}$. For the rest, police interventions arose in case of communal conflict with the native Gentile population and with well-established minorities like the Irish.

Neither the police nor the minority community felt the need for closer relations. Anglo-Jewish leaders in general seem to have regarded the policing of morals as an aid to the socialisation of the Russo-Polish immigrant. The latter, by contrast, accustomed to a more coercive and discriminatory criminal justice system, considered it prudent to maintain a respectful distance from men in uniform. The police themselves, with mixed and uncertain feelings about Jewish settlement, had little desire for greater intimacy. The creation of a cadre of Yiddish speaking policemen, as we have seen, was a measure designed to improve police surveillance of political dissidents rather than the expression of a community relations strategy. The Metropolitan Police, too, made no attempt to secure Jewish recruits, but then they were not pressed to do so. Recent research has shown that Irish-born police recruits came forward in disproportionately large numbers in cities with significant Irish immigrant populations ${ }^{95}$. Within Jewish East London, however, the police service exerted no such appeal. The Jewish community, wary of state officialdom, was in general satisfied with police protection and felt neither need nor desire for police employment. Police work offered the minority population no special facilities for Sabbath observance and was frowned upon by immigrants who equated men in uniform with state oppression. Ambitious parents directed their children elsewhere. Jewish communal leaders were on the whole more concerned with the police priorities in the suppression of vice and criminality than with the social basis of the service. Their ready support and cooperation in the regulation of poverty and prostitution, designed to promote Jewish integration without loss of identity, also served to sustain their own authority. Sometimes the two aims became confused and dangerous as with the attempt to regulate irregular Jewish marriages during the First World War. The willingness of the authorities to extend the criminal law into this area and their reluctance to proceed following the withdrawal of support by 'The Board of Deputies of British Jews' is both interesting and instructive.

The singular importance of Jewish communal leadership, underscored by that episode, requires further comment. Once again it may be helpful to contrast the

\footnotetext{
94 Black (1988, p. 138).

95 Emsley, Clapson (1994, p. 278).
} 
Jewish with the Irish experience. Police-public relations in the Whitechapel ghetto seem to have been free of that endemic antagonism which has elsewhere characterised everyday encounters between the minority population and the constabulary. There is no evidence of intensive and provocative police monitoring or that immigrant Jews were the subject of any other form of systematic discrimination. This, however, has little to do with that growing police professionalism, upon which so much, perhaps too much, scholarly attention has been lavished. Policemen, we have seen, were socially close to indigenous East Enders and shared much of the widespread local anti-Semitism. The stereotypical sentiments, recorded by Booth's investigators, suggest, however, that police attempts to construct a target of the Jewish immigrant as a member of a clearly defined outcast group, were, in the first place, frustrated by the puzzling character of the community. The Jewish community, though it had hardened criminal element, was not perceived as dangerous and disorderly like the Irish. Whether valid or invalid, these perceptions may well have influenced law enforcement practices. Is it possible that the under-representation of Jews in the criminal population and the over-representation of the Irish reflected not the 'real' state of crime but the fact that it was easier to target Irish rather than Jewish immigrants ${ }^{96}$. Is there, too, a connection between the prevalent pattern of policeimmigrant relations in Jewish East London and the nature of Jewish communal leadership? The presence of bourgeois communal leaders who gave ready support to the impartial enforcement of the law but balked at racist and discriminatory policing as contrary to their self-image as Englishmen and Jews, meant not only that the police did not stand alone, but that the monitors were themselves closely monitored. English Catholics, by contrast, were not available to perform a comparable role on behalf of the Irish poor. Nor does there appear to have been an Anglo-Irish middle class ready to step into the breach. The Anglo-Irish middle class, insofar as it existed, seems, for whatever reason, to have lacked the strong sense of communal commitment and solidarity that characterised Anglo-Jewry. It is not the case that policemen have preferred Jews to other immigrant minorities, but it may be the case that they have been constrained to interact with them in a distinctive manner.

\author{
David Englander \\ Revised and corrected \\ by Clive Emsley \\ The Open University \\ c.emsley@open.ac.uk
}

\title{
BIBLIOGRAPHY
}

\section{Manuscript Sources}

TNA (The National Archives, London): HO, Home Office Papers; Mepo, Metropolitan Police Papers; RG, Records of the General Register Office.

96 On the under-representation of Jews in the criminal population, see HO: 45, Statistics and various testimonies as to the character of the Jewish Immigrant, 9 February, 1911; Cohen (1914,pp. 92-94). 
The Booth Collection (TBC).

HL (Hartley Library, University of Southampton) MS 173, Jewish Association for the Protection of Girls, Women and Children: Minutes of the Gentleman's Sub-Committee.

\section{Printed Sources}

Royal Commission on the Housing of the Working Classes, 1884-1885.

Royal Commission on Alien Immigration, 1903.

Select Committee on Emigration and Immigration (Foreigners) 1889.

Select Committee on Sweating, 1888-1890.

Select Committee on Sunday Trading, 1905.

\section{References}

Ascoli, D., The Queen's Peace: The Origins and Development of the Metropolitan Police, 1829-1979, London, Hamish Hamilton, 1979.

Black, E.C., The Social Politics of Anglo-Jewry 1880-1920, Oxford, Blackwell, 1988.

Booth, C., Condition and Occupations of the People of the Tower Hamlets, 1886-1887, London, Edward Stanford, 1887.

Booth, C., Life and Labour of the People in London ( $1^{\text {st }}$ Series 'Poverty' in 4 volumes; $2^{\text {nd }}$ Series 'Industry' in 5 volumes, $3^{\text {rd }}$ Series 'Religious Influences' in 7 volumes including Summary; Final Volume), 17 volumes, London, Macmillan, 1902. Final volume published 1903. [The volumes are numbered by series. The first two series, Poverty and Industry, are revised versions of books published in the 1880s and 1890s].

Brewer, Mrs., The Jewish Colony in London, Sunday Magazine, 1892, XXI.

Bridgeman, I., Emsley, C., A Guide to the Archives of Police Forces in England and Wales, Cambridge, Police History Society, 1989.

Bristow, E.J., Prostitution and Prejudice: The Jewish Fight Against White Slavery 18701939, Oxford, Clarendon Press, 1982.

Cohen, I., Jewish Life in Modern Times, London, Methuen, 1914.

Critchley, T.A., A History of Police in England and Wales, London, Constable 1967.

Davis, J., Jenning's Buildings, in Feldman, D., Stedman Jones, G. (eds), Metropolis London : Histories and Representations since 1800, London, Routledge and Kegan Paul, 1989.

Davis, J., From "Rookeries" to "Communities": Race, Poverty and Policing in London, 18501985, History Workshop Journal, 1989, 27, pp. 66-85.

Dixon, D., From Prohibition to Regulation, Bookmaking, Anti-Gambling and the Law Oxford, Clarendon Press, 1991.

Dyche, J.A., The Jewish Workman, Contemporary Review, 1898, LXIII.

Emsley, C., Clapson, M., Recruiting the English Policeman c.1840-1940, Policing and Society, 1994, 3, 2, pp. 269-286.

Emsley, C., The English Police : A Political and Social History, $2^{\text {nd }}$ edn. London, Longman, 1996.

Emsley, C., Crime and Society in England, 1750-1900, $4^{\text {th }}$ edn. London, Longman, 2010. Englander, D., Landlord and Tenant in Urban Britain, 1838-1918, Oxford, Oxford University Press, 1983.

Englander, D., Anglicized not Anglican: Jews and Judaism in Victorian Britain, in Parsons, G. (ed.), Religion in Victorian Britain Volume I Traditions, Manchester, Manchester University Press, 1988, pp. 235-273. 
Englander, D., Booth's Jews: The presentation of Jews and Judaism in Life and Labour of the People in London, Victorian Studies, 1989, 32, pp. 551-571.

Englander, D., Police and Public Order in Britain, 1914-1918, in Emsley, C., Weinberger, B. (eds), Policing Western Europe, Politics, Professionalism and Public Order. 1850-1940, New York, Greenwood Press, 1991.

Englander, D., Stille Huppah (Quiet Marriage) among Jewish Immigrants in Britain, The Jewish Journal of Sociology, 1992, 34, 1, pp. 85-109.

Englander, D., O'Day, R., Police and social inquiry in late-Victorian London, in Steele, J. (ed.), The Streets of London: The Booth Notebooks, London, Deptford Forum Publishing Ltd, 1997, pp. 1-14.

Fishman, W.J., East End Jewish Radicals, 1870-1914, London, Duckworth, 1973.

Fishman, W.J., East End 1880: A year in a London borough among the labouring poor, London, Duckworth, 1988.

Gainer, B., The Alien Invasion, The Origins of the Aliens Acts of 1905, London, Heinemann, 1972.

Gartner, L.P., The Jewish Immigrants in England, 1870-1914, $2^{\text {nd }}$ edn, London, Simon Publications, 1973.

Goldberg, A., A Jew Went Roaming, London, Samson Row, 1937.

Holmes, C., Anti-Semitism in British Society 1876-1939, London, Edward Arnold, 1979.

Knepper, P., British Jews and the Racialisation of Crime in the Age of Empire, British Journal of Criminology, 2007, 47, 1, pp. 61-79.

Lees, L.H., Exiles of Erin: Irish Migrants in Victorian London, Manchester, Manchester University Press, 1979.

Levine, M., Cheetham to Cordova, A Manchester Man of the Thirties, Manchester, Neil Richardson, 1984.

Lipman, V.D., A Social History of the Jews in England, 1850-1950, London, Watts, 1954.

O'Tauthaigh, M.A.G., The Irish in Nineteenth-Century Britain: Problems of Integration, Transactions of the Royal Historical Society, $5^{\text {th }}$ series, 1981.

Panayi, P., The Enemy in our Midst Germans in Britain during the First World War, New York and London, Berg, 1991.

Petrow, S., Policing Morals: The Metropolitan Police and the Home Office, 1870-1914, Oxford, Clarendon Press, 1994.

Russell, C., Lewis, H.S., The Jew in London, A Study of Racial Character and Present-day Conditions, London, T. Fisher Unwin, 1901.

Samuel, R., East End Underworld: Chapters in the Life of Arthur Harding, London, Routledge and Kegan Paul, 1981.

Shpayer-Makov, H., The making of a Policeman : A social history of a labour force in metropolitan London, 1829-1914, Aldershot, Ashgate, 2002.

Sponza, L., Italian Immigrants in Nineteenth-Century Britain : Realities and Images, Leicester, Leicester University Press, 1988.

Stallard, J.H., London Pauperism amongst Jews and Christians, London, Saunders Otley, 1867.

Swift, R., Gilley, S. (eds), The Irish in the Victorian City, London, Croom Helm, 1985.

Walkowitz, J.R., City of Dreadful Delight, Narratives of Sexual Danger in Late-Victorian London, London, Virago, 1992.

White, J., Jewish Landlords, Jewish Tenants: An Aspect of Class Struggle within the Jewish East End, 1881-1914, in Newman, A., The Jewish East End, 1840-1939, London, The Jewish Historical Society of England, 1981. 